\title{
Antifungical action of different concentrations of garlic extract in watermelon seeds
}

\author{
Ana Carolina Pinguelli Ristau ${ }^{1}$, Maria Soraia Fortado Vera $\mathrm{Cruz}^{1}$, Shirlene Souza Oliveira ${ }^{1}$, Thatiane Nepomuceno Alves ${ }^{1}$, \\ Hannah Braz ${ }^{1}$, Marlene de Matos Malavasi ${ }^{1}$, Ubirajara Contro Malavasi ${ }^{1}$ \\ ${ }^{1}$ State University of Western Parana, Center for Agrarian Sciences, Postgraduate Program in Agronomy, 1777, Pernanbuco Street, PO Box 91, Marechal Cândido \\ Rondon, Parana, Zip: 85960000, Brazil.
}

Correspondence Author: Ana Carolina Pinguelli Ristau, State University of Western Parana, Center for Agrarian Sciences, Postgraduate Program in Agronomy, 1777 Pernanbuco Street, PO Box 91, Marechal Cândido Rondon, Parana, Zip: 85960000, Brazil.

E-mail: ana_ristau@hotmail.com.

\section{Received date: 12 June 2018, Accepted date: 14 September 2018, Online date: 25 September 2018}

Copyright: (C) 201x Ana Carolina Pinguelli Ristau. This is an open-access article distributed under the terms of the Creative Commons Attribution License, which permits unrestricted use, distribution, and reproduction in any medium, provided the original author and source are credited.

\begin{abstract}
The watermelon (Citrullus lanatus Thumb. Mansf.) belonging to the family of the cucurbits, is a plant native to the tropical regions of Equatorial Africa. For a satisfactory production it is necessary to use seed with high quality, i.e., seeds able to play their vital functions. The sanitary quality has an important role for the successful production of vegetables because the presence of pathogens has direct effects on the force, seedling establishment and yield in field, which can cause considerable damage to the production system. The use of extracts obtained from plants can be considered an alternative for control of pathogenic microorganisms to seed, because they have some advantages, such as reduced spending and the environmental impact caused by the use of chemicals. The study aimed to evaluate the effects of differents concentrations of garlic extract in the physiological potential and its antifungal action in seeds of watermelon cultivar Charleston Gray. Watermelon seeds were submerged for a minute in concentrations of $0 \%, 25 \%, 50 \%$ and $75 \%$ of garlic extract. Then, they were submitted to the germination test in gerbox type boxes. During the germination test were counted daily the number of normal and abnormal seedlings. Based on the data were calculated the percentage of germination, percentage of normal and abnormal seedlings and dead seeds, the average speed of germination, germination medium time and germination speed index. At the end of the germination test we calculated the fungal incidence in the seeds. The concentrations of garlic extract tested have negative effects on physiological potential of soybean seeds cv. Charleston Gray, because there was a decrease in the percentage of germination with the highest concentration of garlic extract concomitantly, there was an increase in the percentage of abnormal seedlings and dead seeds. The garlic extract presents high efficiency in the control of fungi in watermelon seed because the seed treatment with the extract inhibited the incidence of fungi. The use of garlic extract in the control of fungi in seeds of watermelon proved highly effective, because at the lowest concentration tested, it was possible to eradicate the incidence of fungi in watermelon seeds cv. Charleston Gray, contrasting to what was observed in the non-treated seed where fungal observed high incidence. However, in spite of the efficiency in antifungal action, the garlic extract, at the concentrations used caused deleterious effects on seed physiological potential, as found in the germinative potential reduction and less force, in addition to the increase in the percentage of abnormal seedlings and dead seeds, in the highest concentration (75\%) there was the inhibition of seed germination
\end{abstract}

Key words: Citrullus lanatus, vegetable extract, fungal incidence, germination and vigor of seeds.

\section{INTRODUCTION}

The watermelon (Citrullus lanatus Thumb. Mansf.) belonging to the family of the cucurbits, is a plant native to the tropical regions of Equatorial Africa. In Brazil, is considered one of the most important vegetables, both for its nutritional qualities but also for its commercial value (Andrade Junior et al., 2007). The spread of this is performed by seeds being sown directly in the field or in substrates for production of seedlings (Nery et al., 2007).

For a satisfactory production it is necessary to use seed with high quality, i.e., seeds able to play their vital functions (Toledo et al., 2009). The term seed quality is related to the characteristics relating to the genetic properties, physiological, and sanitary conditions of the seed, so the production of seed aims to achieve seeds with these characteristics (Carvalho and Nakagawa, 2012).

The sanitary quality has an important role for the successful production of vegetables because the presence of pathogens has direct effects on the force, seedling establishment and yield in field, which can cause considerable damage to the production system (Nascimento et al., 2011). Being the sanitary treatment of seeds one of the most recommended measures for controlling diseases in the stage that precedes the deployment of culture. One of the alternative methods of pest control would be the use of plant extracts in the treatment of seeds (Silva et al., 2010). The use of extracts obtained from plants can be considered an alternative for control of pathogenic microorganisms to seed, because they have some advantages, such as reduced spending and the environmental impact caused by the use of chemicals (Coutinho et al., 1999). Several studies have demonstrated the efficiency of the use of plant extracts on phytosanitary control of seeds of differents species, such as garlic extract in corn seeds (Souza et al., 2007) and in seeds of cedar (Lazarotto et al., 2013), extract Momordica charantiaand and Allamanda cathartica in seeds of Pterogyne nitens Tul (Medeiros et al., 2013). 
Citation: Ristau1, A. C. P. et al., 2018. Antifungical action of different concentrations of garlic extract in watermelon seeds. Australian Journal of Basic and Applied Sciences, 12(9): 157-161.

The use of vegetable extract in the treatment of seeds must be made judiciously because their effects depend, often of the compounds present in the plant, since this can present some allelopathic effects that can cause the inhibition of germination (Lazarotto et al., 2013). The same authors, studying methods of sanitary treatment of seeds of Cedrela fissilis observed efficiency of garlic extract in the control of pathogenic micro-organism. The extract of Allium sativum (garlic) has toxic substances inhibitory effects on various bodies (Dos Santos and Stadnik, 2004).

Therefore the objective of this work was to evaluate the effects of differents concentrations of garlic extract in the physiological potential and its antifungal action in seeds of watermelon cultivar Charleston Gray.

\section{MATERIAL AND METHODS}

The study was conducted at the Seed Technology Laboratory of State University of Western Parana (UNIOESTE), Marechal Cândido Rondon campus. Seeds of watermelon, cultivar Charleston Gray, acquired in local trade.

The garlic extract was obtained with the use of $50 \mathrm{~g}$ of immature bulbs of garlic along with $100 \mathrm{~mL}$ of distilled water, crushed in a blender. And subsequently filtered and from this we obtained the following concentrations: T0, Witness - $0 \%$ of extract, only distilled water; T1: $25 \%$ extract and 75\% of distilled water; T2: 50\% extract and 50\% of distilled water; T3: $75 \%$ extract and 25\% of distilled water.

The seeds were submerged in the extract for one minute, and then sowed on filter paper, moistened with the extract 2.5 times the value of their weight, and kept in chambers of the BOD type, with a temperature of $25{ }^{\circ} \mathrm{C}$ in the presence of light for 12 hours.

During the germination test were counted daily the number of normal and abnormal seedlings, with criteria determined by the Rules for Seed Analysis (RAS) (Brazil, 2009). Based on the data were calculated the percentage of germination, percentage of normal and abnormal seedlings, the average speed of germination (ASG), the mean germination time (MGT) and the germination speed index (GSI).

The calculations of the percentage of germination, the ASG and MGT were performed according to Labouriau (1983):

$$
\mathrm{G}(\%)=(\mathrm{N} / \mathrm{A}) \mathrm{x} 100
$$

Where: $\mathrm{G}$-percentage of germination; $\mathrm{N}$-number of germinated seeds; $\mathrm{A}$ - the total number of seeds placed to germinate.

$$
\text { MGT }=\frac{\sum \text { nt .ti }}{\sum \text { ntotal }} \text { (days) }
$$

Where: MGT refers to the average time of germination in days; nt is the number of germinated seeds in a time interval; it is the time interval; ntotal is the total number of germinated seeds.

$$
\mathrm{ASG}=\frac{1}{\mathrm{t}} \text { (seeds/day) }
$$

Where: $t$ is the average time of germination; ASG is the average speed of germination.

And the germination speed index was calculated from the formula presented by Maguire (1962):

$$
\mathrm{GSI}=\frac{\mathrm{G} 1}{\mathrm{~N} 1}+\frac{\mathrm{G} 2}{\mathrm{~N} 2}+\cdots+\frac{\mathrm{Gn}}{\mathrm{Nn}}
$$

In that: GSI - germination speed index; $\mathrm{G}$ - number of germinated seeds; $\mathrm{N}=$ number of days from sowing.

At the end of the germination test seeds were analyzed with the aid of a stereoscopic microscope to identify and quantify in percentage (\%) for the presence of fungi. Each seed was viewed individually. The identification of fungi occurred by means of comparison of the structures found with the characteristics described in the specific literature.

The experiment was conducted in a completely randomized design with 4 treatments and 7 replications of 15 seeds. The results were submitted to analysis of variance and regression analysis.

\section{RESULTS AND DISCUSSION}

In Table 1 are shows the average percentage of germinated seeds, and non-germinated, watermelon, treated with differents concentrations of garlic extract. There was no statistically significant difference $(\mathrm{p} \leq 0.05)$ among the differents treatments (concentration of garlic extract) for percentage of germination (G), abnormal seedlings (AS) and dead seeds (DS).

The largest percentage of germination, $59.05 \%$ was observed for the non-treated seed ( $0 \%$ concentration) with garlic extract, followed by the seeds treated with the lowest concentration of the extract. There is a decrease in the percentage of germinated seeds to the extent that there is an increase in the concentration of garlic extract, where the highest concentration tested $(75 \%)$ completely inhibited the germination of the seeds.

Simultaneously, we observed an increase in the percentage of abnormal seedlings and dead seeds concomitant to the increase in the concentration of garlic extract in the treatment of seeds of watermelon, namely, $29.52 \%, 58.10 \%, 71.43 \%$ and $80 \%$ of AS, respectively, for the seeds treated with $0 \%, 25 \%, 50 \%$ and $75 \%$ concentration of garlic extract, for the percentage of DS, the averages were, $11.43 \%$, $12.38 \%$, $24.76 \%$ and $20 \%$, respectively, for the concentrations of $0 \%, 25 \%, 50 \%$ and $75 \%$ concentration of garlic extract.

Table 1. Percentage of germination (G), abnormal seedlings (AS) and dead seeds (DS) of watermelon seeds cv. Charleston Gray, subjected to differents concentrations of garlic extract.

\begin{tabular}{cccc}
\hline Concentration & G $\%$ & AS\% & DS \% \\
\hline $0 \%$ & $59.05 \mathrm{a}$ & $29.52 \mathrm{c}$ & $11.43 \mathrm{c}$ \\
$25 \%$ & $29.52 \mathrm{~b}$ & $58.10 \mathrm{~b}$ & $12.38 \mathrm{c}$ \\
$50 \%$ & $3.81 \mathrm{c}$ & $71.43 \mathrm{ab}$ & $24.76 \mathrm{~b}$ \\
$75 \%$ & $0.00 \mathrm{c}$ & $80.00 \mathrm{a}$ & $20.00 \mathrm{a}$ \\
\hline $\mathrm{CV} \%$ & 20.17 & 18.44 & 20.57 \\
\hline
\end{tabular}

Medium followed by the same letter in column do not differ by Tukey test $(\mathrm{p} \leq 0.05)$.

The mean germination time (MGT), average speed of germination (ASG) and germination speed index (GSI) in germination of seeds of watermelon cv. Charleston Gray treated with differents concentrations of garlic extract are shown in Figure 1.

The seeds of watermelon presented quadratic behavior $(y=-0,0026 \times 2+0,0363 x+11.179)$ for the mean germination time (Figure 1). The seeds were not treated with garlic extract ( $0 \%$ concentration) presented MGT of 10 days for the seeds treated with $25 \%$ of garlic extract, there was an increase of 3 days in average time for germination. However, in higher concentrations showed a significant reduction in the MGT, with averages of 4 and 0 days for the concentrations of $50 \%$ and $75 \%$, respectively. These drastic reductions in the average time for the highest 
Citation: Ristau1, A. C. P. et al., 2018. Antifungical action of different concentrations of garlic extract in watermelon seeds. Australian Journal of Basic and Applied Sciences, 12(9): 157-161.

concentrations of garlic extract are related to the low percentage of germination (Table 1) observed for these treatments, since the formula to calculate the MGT, proposed by Labouriau (1983) considers the number of germinated seeds.

For the average speed (Figure 1-B) and to the speed index (Figure 1-C) of germination of seeds of watermelon treated with differents concentrations of garlic extract, it is observed a linear reduction in function of the increase in the concentration of extract.
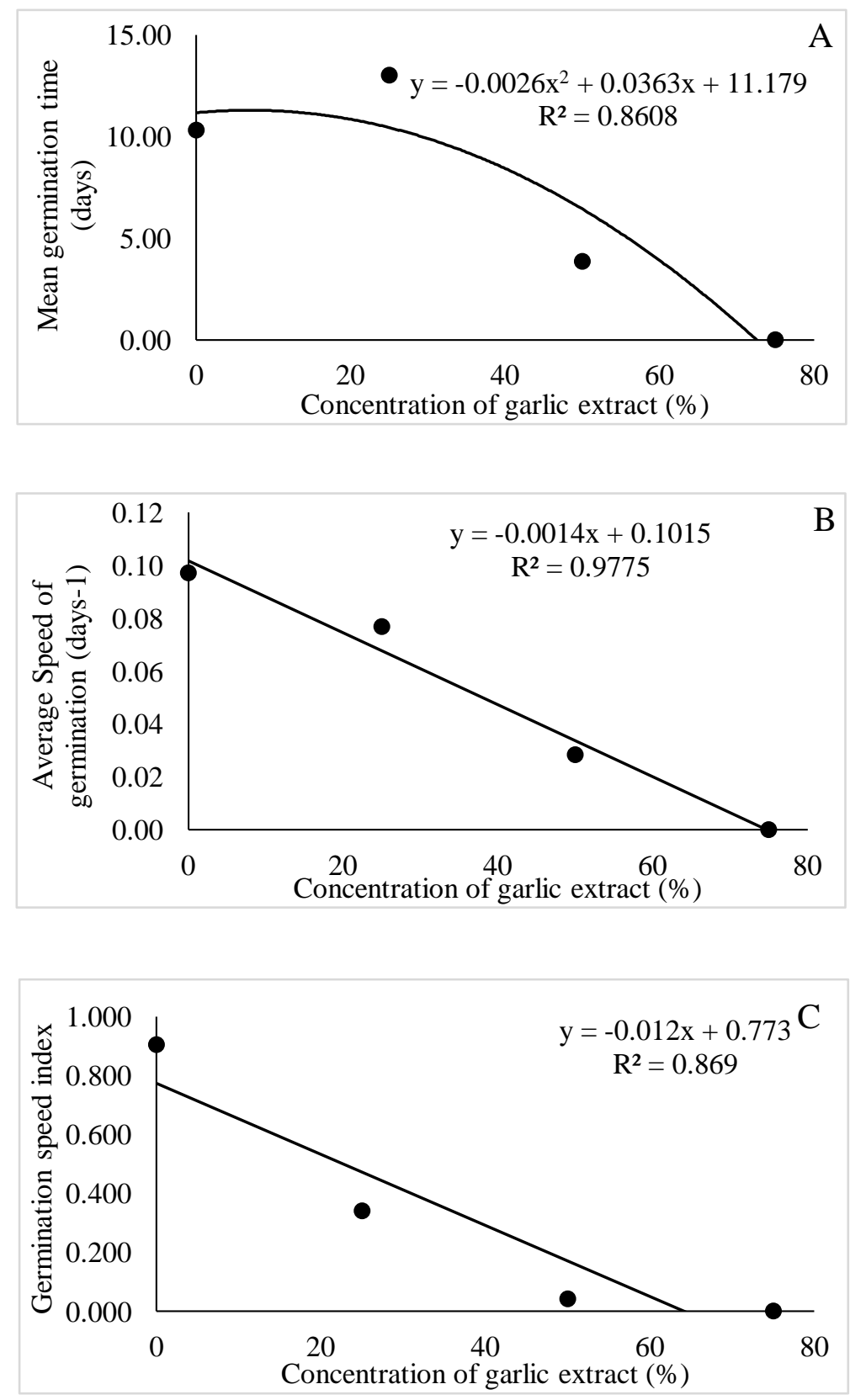

Fig. 1: Mean germination time (A), average speed of germination (B) germination speed index (C) of watermelon seeds exposed to differents concentrations of garlic extract.

In accordance with the data in Table 1 and Figure 1 it can be inferred that the concentrations of garlic extract tested have negative effects on physiological potential of soybean seeds cv. Charleston Gray, once the lowest dose tested $(25 \%)$ was sufficient to considerably reduce the germination percentage of seeds, in this case, it is suggested that further studies be performed in lower concentrations to be elucidated the conclusive effect of garlic extract in the treatment of seeds of this species.

In Table 2 are averages of incidence of fungi in seeds of watermelon in function of differents concentrations of garlic extract. It is observed that the lower concentration used of garlic extract $(25 \%)$ have proved to be efficient to completely eliminate contamination by fungi in seeds of watermelon. On the other hand, we observed a high incidence of fungi, especially of the genera Aspergillus and Penicillium, in watermelon seeds were not treated. Souza et al. (2007) also observed antifungal efficiency of garlic extract when tested in maize seeds.

Lazarotto et al. (2013) studied the use of garlic extract in the treatment of seeds of Cedrela fissilis and verified that it was efficient, because the application of the extract resulted in a higher percentage of healthy seeds, results similar to those observed in this study with seeds of watermelon, however, differently from what was observed for the seeds of watermelon, the use of garlic extract in seeds of Cedrela fissilis favored its germination and vigor. 
Citation: Ristau1, A. C. P. et al., 2018. Antifungical action of different concentrations of garlic extract in watermelon seeds. Australian Journal of Basic and Applied Sciences, 12(9): 157-161.

Table 2. Incidence (\%) of fungi in watermelon seeds cv. Charleston Gray, treated with differents concentrations of garlic extract.

\begin{tabular}{cccccc}
\hline Concentration & Aspergillus flavus & Aspergillus niger & Aspergillus sp. & Penicillium spp. & Cladosporium sp. \\
\hline $0 \%$ & 7.62 & 3.81 & 11.43 & 69.52 & 0.95 \\
$25 \%$ & 0.00 & 0.00 & 0.00 & 0.00 & 0.00 \\
$50 \%$ & 0.00 & 0.00 & 0.00 & 0.00 & 0.00 \\
$75 \%$ & 0.00 & 0.00 & 0.00 & 0.00 & 0.00 \\
\hline
\end{tabular}

In a study conducted by Souza et al. (2010) with differents concentrations of garlic extract (0\%, 50\%, 75\% and $100 \%)$, in the treatment of seeds of Inga edulis, it was possible to confirm the effectiveness of the extract to some fungi (Aspergillus candidus, Rizophus sp, Aspergillus flavus and Trichoderma) while for some was not effective (Aspergillus alutaceous, Aspergillus niger). As Lopes et al. (2011), also working with garlic extract in seeds of Anadenanthera colubrina found no antifungal effect of this. While this work the garlic extract was effective for all fungi that were featured in the witness, even at the lowest dose $(25 \%)$.

The data in Table 2 indicate that the garlic extract presents high efficiency in the control of fungi in watermelon seed because the seed treatment with the extract inhibited the incidence of fungi. However, further studies should be performed to determine a concentration effective as antifungal action and at the same time does not adversely affect the germination and seed vigor.

\section{CONCLUSIONS}

The use of garlic extract in the control of fungi in seeds of watermelon proved highly effective, because at the lowest concentration tested, it was possible to eradicate the incidence of fungi in watermelon seeds cv. Charleston Gray, contrasting to what was observed in the non-treated seed where fungal observed high incidence. However, in spite of the efficiency in antifungal action, the garlic extract, at the concentrations used caused deleterious effects on seed physiological potential, as found in the germinative potential reduction and less force, in addition to the increase in the percentage of abnormal seedlings and dead seeds, in the highest concentration (75\%) there was the inhibition of seed germination.

It is recommended that further studies be conducted in order to test new dosages of garlic extract, in lower concentrations, in order to achieve the optimal amount for control of incidence of fungi that occur without loss of germination potential and damage to the seed vigor.

\section{REFERENCES}

Andrade Júnior, A. S., Rodrigues, B. H. N., Athayde Sobrinho, C., Bastos, E. A., Melo, F. B., Cardoso, M. J., Silva, P. H. S., Duarte, R. L. R., 2007. A cultura da melancia. Embrapa Meio-Norte.

Bhering, M. C., Dias, D. C. F., Barros, D. I., Dias, L. A. S., Tokuhisa, D., 2003. Avaliação do vigor de sementes de melancia (Citrullus lunatus Schrad.) pelo teste de envelhecimento acelerado. Revista Brasileira de Sementes. 25 (2):1-6.

Carvalho, N. M., Nakagawa, J., 2012. Sementes: ciência, tecnologia e produção. Funep.

CASAROLI, D., GARCIA, D.C., MUNIZ, M.F.B \& MENEZES, N.L., 2006. Qualidade sanitária e fisiológica de sementes de abóbora variedade Menina Brasileira. Fitopatologia Brasileira. 31 (2):158-163.

Coutinho, W. M., Araújo, E., Magalhães, F. H. L., 1999. Efeitos de extratos de plantas anacardiáceas e dos fungicidas químicos benomyl e captan sobre a microflora e qualidade fisiológica de sementes de feijoeiro (Phaseolus vulgaris L.). Ciência e Agrotecnologia, 23 (3): $560-568$.

Labouriau, L.G., 1983. A germinação de sementes. OEA.

Lazarotto, M., Muniz, M. F. B., Beltrame, R., Santos, A. F., Mezzomo, R., Piveta, G., Blume, E, 2013. Qualidade fisiológica e tratamentos de sementes de Cedrela fissilis procedentes do sul do brasil. Revista Árvore, 37 (2) : 201-210.

Lopes, I. S., Campelo, G. J., Bezerra, R. M. R., Assis, M. M., Rangel, J. A. F., 2011. Avaliação antifúngica do extrato de Allium sativum L. no controle de fungos em sementes de Anadenanthera colubrine. Revista de Biologia e Farmácia, 6 (1): 145150.

Maguire, J. D., 1962. Speed of germination aid in selection and evaluation for seeding emergence and vigor. Crop Science, 2 (2) : 76-177.

Medeiros, J. G. F., Araujo Neto, A. C., Medeiros, D. S., Nascimento, L. C., Alves, E. U., 2013. Extratos Vegetais no Controle de Patógenos em Sementes de Pterogyne nitens Tul. Floresta e Ambiente, 20 (3): 384-390.

Nascimento, W. M., Dias, D. C. F. S., Silva, P. P., 2011. Qualidade da semente e estabelecimento de plantas de hortaliças no campo. In Hortaliças: tecnologia de produção de sementes, Eds., Nascimento, W. M. Brasília: Embrapa Hortaliças, pp.79-106.

Nery, M. C., Carvalho, M. L. M., Oliveira, L. M., 2007. Teste de tetrazólio para avaliação da qualidade fisiológica de sementes de melancia. Semina: Ciências Agrárias, 28 (3): 365-372.

Talamini, V. e Stadnik, M. J., 2004. Extratos Vegetais e de Algas no Controle de Doenças de Plantas. In Manejo Ecológico de Doenças de Plantas. Eds., Talamini, V. e Stadnik, M. J. Florianópolis, SC: CCA/UFSC, pp. 45-62. 
Citation: Ristau1, A. C. P. et al., 2018. Antifungical action of different concentrations of garlic extract in watermelon seeds. Australian Journal of Basic and Applied Sciences, 12(9): 157-161.

armazenamento de sementes de feijão em função da aplicação tardia de nitrogênio em cobertura. Pesquisa Agropecuária Tropical, 39 (2): 124-133.

Silva, G. H., Souza, P. F., Henriques, I. G. N., Campelo, J. G., Alves, G. S., 2010. Extrato de alho e nim em diferentes concentrações com efeito fungicida em sementes de chorão (Poecilanthe ulei). Revista Verde, 5 (4): $76-81$.

Souza, A. E. F., Araújo, E., Nascimento, L. C., 2007. Atividade antifúngica de extratos de alho e capim-santo sobre o desenvolvimento de Fusarium proliferatum isolado de grãos de milho. Fitopatologia Brasileira, 32 (1): 465-471.

Souza, P. F., Silva, G. H., Henriques, I. G., Campelo, G. J., Alves, G. S., 2010. Atividade antifúngica de diferentes concentrações de extrato de alho em sementes de ingá (Inga edulis). Revista Verde, 5 (5): 8-13. 